

ELS-JISH

ELS Journal on Interdisciplinary Studies on Humanities

Volume 2 Issue 2, 2019

ISSN (print) : 2621-0843

ISSN (online) : 2621-0835

Homepage : http://journal.unhas.ac.id/index.php/jish

\title{
French Modality of Verb Modal in Directive Acts on Michel Vaillant's Comic
}

\author{
Yuliantini $^{1}$, Sumarlam ${ }^{2}$, Tri Wiratno ${ }^{3}$ \\ ${ }^{1}$ bintangbulansejahtera@gmail.com
}

\begin{abstract}
Each language has a modality to express the speaker's attitude. The form that describes the attitude of the speaker is in the form of grammatical elements and there are also lexical elements. In French, the lexical attitude of the speaker can be characterized by capital verbs such as vouloir, devoir, pouvoir and falloir. This paper discusses the modalities in directive speech acts in its use in French in French-language comics namely Michel Vaillante. This article aims to find out the function of using modal modal verb modalities realized by Michel Vaillante comics. Data is collected from Michel Vaillante comics downloaded from the online version of the Culturethèque website. Data collection was done using the 'see' method, then analyzed using the agih method with the basic technique 'for direct elements'. The last step is the method of presenting data. The author uses formal and informal methods in presenting the results of data analysis. The results show that the function of the French modal modal verb in directive speech acts expresses the meaning of governing, suggesting, and expressing hope. The capital verbs used are devoir, pouvoir, vouloir, and falloir.
\end{abstract}

Keywords: Modalities, French, Capital Verbs, Directive Speech Acts

How to cite: Yuliantini, et al. (2019). French Modality of Verb Modal in Directive Acts on Michel Vaillant's Comic. ELS Journal on Interdisciplinary Studies in Humanities, 2 (2), 278-290

\section{Introduction}

Modalities are related to the attitude of the speaker. The form that describes the attitude of the speaker is in the form of grammatical elements, and some are lexical (Alwi, 1992: 2). The grammatical picture of the speaker's attitude, commonly called fashion, is seen in the use of special verb forms, such as the Indo-European family language. The following example in France shows that the subordinate clause verb on (1) is expressed in the form of indicative mode and at (2) with the subjunctive mode form of "vienne".

(1) . Je crois qu'il vient

(2) Je ne crois pas qu'il vienne.

According to Lyon (in Alwi, 1992: 29), the example of French in (1), (2) can be expressed again in English each through (1a), (2a) so that both are il vient and il 
vienne. Construction translates to 'he will come'. (1a) I think he will come. (2a) I don't think he will come. In this case, modalities are very related to fashion. The sentence is said to contain a mode when containing the concept of modality. Translation modalities must be distinguished from the notion of fashion, because the two terms together describe the attitude taken by the speaker. Alwi (1992: 4) suggests that differences with fashion, which are both attitudes taken by the speaker, lie in the category. Mode is a grammatical category, while modality refers to meaning. The semantic concept of modality is manifested through fashion. The form of grammatical modality as a nontemporal function at that time, in French is expressed in indicative, subjunctive, imperative, infinitive and participe modes (au quel on associe le gerondif) (L'Huillier: 2009: 510). In addition to functioning as a marker of time and aspects, in the form of certain tenses also function to reveal the function of modalities, which means with certain forms, namely the form of the future (simple futures) that is simple for example, this form can reveal modalities. The simple futuristic example that expresses the modality of will can be seen in the following sentence: J'irai Paris. 'I will go to Paris".

Meanwhile, the lexical expression of the speaker's attitude means that the form of language used is classified as a word, phrase, or clause. In English it is seen in the use of certain auxiliary verbs, adverbs such as 'maybe', or in construction as 'certain that [...]'. In Indonesian the lexical expression of the speaker's attitude can be exemplified by the use of verbs such as those that will and should, adverbs as they should and perhaps, or clauses I think and I want. In French, lexical modalities can be characterized by modal verbs such as vouloir, devoir, pouvoir, adverb such as peut-être, sans doute, malheureusement, adjectives such as génial, stupide, agréable.

There are several verbs in bP that are capable of expressing modalities namely devoir and pouvoir verbs (Dubois, 1969: 118). While Roger Hawkins and Richard Towell mention that the verbs of French capital are divided into four, namely devoir, pouvoir, savoir and falloir. According to L'Huillier (2009: 273), modalities with lexical working capital in French are categorized into three parts, namely devoir, pouvoir, and vouloir. As capital or semi-auxiliary, devoir, pouvoir, and vouloir followed by infinitive. Problems often occur with 'capital' because: (1) capital can have different meanings depending on time and depending on the sentence whether affirmative or negative, (2) modal auxiliary verbs that are the same in the same form can have several meanings based on context .

L'Huillier's statement provides a foundation for researchers that modal auxiliary verbs have many meanings depending on the context of the speech that is available. In his book Pragmatic Principles, Leech (2015: 42) exemplifies the use of modal verbs in the following pragmatic context.

(3) Can you repair this time?

In terms of grammar, sentence (3) can be called a request and not a question because it can be associated with elements and structures that are more like requests and imperatives. The sentence (3) above is stated as an indirect application and begins with a modal can verb. Discussion of the verb of capital cans that function as the above request is clear that there is an overlap between grammar and pragmatics. There are several factors that determine what is meant by speakers 
with their speech, namely the conditions observed, speech, and context. Based on these factors, the opponent is in charge of concluding possible interpretation.

Searle (in Leech, 2015: 48) explains interpretations, specifically the interpretation of indirect ilokusi-ilokusi, for example, Can you pass the salt? (Please give the salt). Can you pass the salt? is an indirect illocution. According to Searle, indirect illocution is illocutionary acts carried out indirectly through other illocutionary acts. The use of modal verb modalities is also closely related to sustainability. The interpretation of illocutionary indirectly like Can you pass the salt? Contains the meaning that the speaker wants the opponent to say get salt.

In relation to speech acts, illocutionary speech acts are classified by Searle into five types, namely assertive, directive, commissive, expressive, and declarative. The classification is based on illocution point (illocution point), direction of fit, and psycological state (Searle in Ubaidah, 2018: 26). The purpose of self-directing illusory discussion in general is that the speaker's business makes the speech partner do something so that the direction of matching such speech is the world that adjusts to the word or directive speech trying to change the world (world to word). The psychological state underlying the directive speech is the desire of the speaker to make the speech partner perform the actions contained in the speech so that he can change the world according to his wishes. Therefore, basically directive illocutionary speech acts are expressions of the desire of the speaker so that the actions contained in the speech are performed (Searle, 1969: 65).

Illocutionary speech acts can be realized in various forms. The most common distinction is direct speech, which means speech illocutionary power is the same as sentence meaning (locution) and indirect illocutionary speech act which means illocutionary power and sentence meaning do not have a direct connection and must be explained by conversational implicature patterns (Leech, 1993: 49- 50). According to Parker (2014: 37-39 and 42-43) the type of speech act can be classified based on the alignment of the speaker's intent with speech intent and mode or the form of the speech sentence. The type of speech act based on the alignment of the speakers' meanings with meaning will result in a type of literal and non-literal speech acts, while based on the harmony of the intention of the speaker with the mode of speech sentences produce a type of direct and indirect speech acts.

Blum-Kulka (in Ubaidillah, 2018: 27) also compiled nine strategies for the realization of illocutionary speech acts based on the degree of continuity to examine the asking action which is a function of direct speech acts and by Podobinska (2002) the Blum-Kulka realization strategy was used to explain directive speech acts in general in Swahili. This Blum-Kulka realization strategy contains many uses of modal verb modalities. This can be seen in the following table.

Table 1. Strategy for Realization of Directive Actions

\begin{tabular}{l}
\multicolumn{1}{c}{ Description } \\
\hline 1. Sentence with an imperative mood \\
(Mood dérivable) \\
Grammatically, the verb mode in \\
utterance marks illocutionary power.
\end{tabular}


The illocutionary power of speech is explicitly mentioned in utterances by speakers.

3. Hedged performative. The mention of illocutionary power is preceded by speech which becomes an illocutionary power fence.

4. Derived from speech locution (Locution derivable)

The illocutionary intention is directly derived from the semantic meaning of speech locus. Usually in this type word must or should be referred to as a statement of necessity.

5. Scope stating Explicit. Expressions of intentions, desires, or feelings as opposed to the fact that the partner does $\mathrm{X}$. Expression makes this type of strategy can be called a statement of desire.

6. Suggestion Formulas (Language specific suggestory formula)

The sentence contains a suggestion for $\mathrm{X}$.

7. Referring to the state of preparation (Reference to preparatory Conditions) Examinations contain references to the conditions of preparation, such as willingness, the possibility to do $\mathrm{X}$.

8. Strong Hints

Exams contain a partial reference to the object or element needed for the implementation of an action that pragmatically directly implies action.

9. Mild hints

Examinations do not refer to directive actions but can be interpreted as such through the context or indirectly have pragmatic implications. at home

Actually I need lecturer number $\mathrm{X}$.

Sinta, we have to clean our room.
I want to go to college, sir. Can I add my permission?

We'd better clean our room.

Sinta, can you clear the board? There is a lot of garbage.

Sinta, this room is not a room for anyone, but a room for two people. Right. Come on, I'll help you too.

My oh my, how dirty is that?

(Blum-Kulka in Ubaidillah, 2018: 27)

Based on the directional speech act realization strategy from Blum-Kulka above, researchers are interested in exploring further about the function of using modal verb modalities in directive speech acts because the strategy of realization of the Blum-Kulka directive speech act above contains many uses of capital verbs. In addition, to determine the function of modal verb modalities, it is necessary to shake the utterance propositions and other aspects of the situation in investigating the meaning or function of a speech. In more detail Halliday (Halliday, 1994: 11-12) 
explains the components of the context of the situation of a language use proposed by Dell Hymes, namely the form and content of the message, the typical environment such as time and place, involvement in the use of language, intent and impact instructions, brokers, genres, and communication norms.

The author reads several writings and research related to capital and modalities. The author found a dissertation written by Nicola M. Brewer with the title Modality and Factivity: One Perspective on the Meaning of the Engish Capital Auxiliaries (1987). Brewer tries to analyze the relationship of the meaning of modalities revealed by English capital with activity. In his research Brewer proved that the main feature of modality is the activation of propositions and non-facts of events revealed in speech.

The discussion of modalities in the Indonesian language was also written by Hendarto Suparta in his thesis Marker of Modalities in the Declarative Sentence of Indonesian Language (1989). Supatra writes that each declarative sentence has two meanings as its elements, one of which is the modality that is the attitude of the speaker towards what he expresses. Supatra analyzes the forms and characteristics of markers of morphemic modalities in declarative sentences in Indonesian. The markers of the attitude of the speaker are then classified into eight subcategories marking modalities based on their meanings.

Soenarjo (1989) writes Indonesian modalities as semantic categories which are expressed lexically in sentences. From there he determines the existence of twentytwo types of sentences that have different meanings based on revealing the meaning of modalities. The author sees that the determination of the subcategories of the types of modalities found in the Supatra and Soenarjo studies tend to be based on the lexical meaning of expressing the modalities used so that the determination of the subcategories of modalities becomes inefficient. In addition, in the study, modality as a speaker's attitude has not been seen as the reader's mind regarding propositions and events.

Furthermore, the discussion on capital verbs as a disclosure of modality was written by Teguh Dwi Cahyadi (2015) in his thesis entitled Capital Assistive Verbs as a Disclosure of English Language Modalities and their Matches in Indonesian. In his research, Cahyadi analyzed the disclosures of modalities (epistemic, deontic, and dynamic) in the form of modal auxiliary verbs in English which were combined with the form of expressing modalities in the Indonesian language.

The discussion of French language modalities was expressed by Herman Parret in 2016 through his scientific article entitled La Pragmatique des Modalités, concluding that first, there is a problem of pragmatic status vis-a-vis the semantics, meaning no one can deny that the semantic problem cannot be free from the pragmatic context. There are both shifts in the modality of the modality predicate into the modality of the proposition.

In addition, a discussion about French modalities was also revealed by Catherine Fuchs in 2016 in her article entitled L'opérateur pouvoir: valeurs, interprétations, reformulations. This article shows the characterization of values in the context of the modal modality of pouvoir verbs from a polysemic perspective, namely the verbs of capital have many meanings in accordance with the context surrounding it. 
Linguistic research related to directive speech acts has been carried out. The first research that was used as a reference was the Desertation of Nadar (2006) about "Rejection in English and Indonesian. Pragmatic Study of the Realization of the Political Courtesy Strategy. It discusses forms of rejection in English and Indonesian based on the types of speech acts contained in the rejection speech. The results of this study gave rise to directive speech acts that were used as elements of rejection in English and Indonesian and the context of the situation that occurred.

Furthermore, Jalal (2006) in his thesis "Speech Actions in the Javanese Dialect of the Language of Surabaya in Ludruk Kartalo Stories" describes the types and uses of the Surabaya dialect directive speech forms. From this study, two types of directive speech acts were found 1) direct directive speech using (1) imperative mode, (2) explicit performative speech, (3) speech by asking for approval, statement of necessity, and threat. 2) speech indirect directive by using speech statement of desire, suggestion, question, innuendo, declarative, and always. Whereas in the use of a variety of directive speeches in various Javanese dialect languages there are differences from various contexts of the speech situation and its pragmatic settings, the use of directive speech does not directly strengthen the quality of the directive speech rather than indirect speech. In this study the variety of informal languages used is a variety of spoken languages in the form of Ludruk Kartalo stories.

In addition, the speech act research by Ad. Darraji et al. (2012) examined bidding as a commissive speech act and directive of a study of cross-cultural communication. This study discusses variations in offerings from various perspectives. Bidding as a commissive and directive speech act is seen from philosophical, social, and cultural perspectives. The results of the study indicate that the specific strategy used by British people to offer is to use the words "could, would, should, will, and shall" which usually function as interrogative sentences. In addition, they emphasize what you want to know to your opponent by using the words perhaps, and if clause, to refine.

Furthermore, Nadar in his next study (2009), which was related to language politeness using data in the form of speeches, showed the politicians' polite speech by following certain maxims and also the speeches of irreverent politicians based on maxims who were considered universally recognized in their use. language. Political language that is not polite is expressed because of pressure or external factors. In addition, from the delivery of politicians, the use of language politeness also influences the vote acquisition in general elections.

The similarity between the previous research and this research is to examine the modalities and directive speech acts. All previous studies examined modalities on lexical aspects only. In this study assessing modality is associated with sociopragmatic contexts; the difference between previous research and this research is, if previous research, research on the topic of modality only focuses on internal factors, while this research, modality is associated with external factors, namely the context surrounding it so that it may cause different functions or meanings.

This research was conducted with the following considerations. The text of the story in the Michel Vaillant comic is a text of dialogue between the characters. Michel is the name of the main character in the comic, and Vaillante is the name of his 
family's automotive company. The language used is very complex, including the use of modal verb modalities in directive speech acts in the conversation. This is very interesting to study considering that modal verb modalities can contain different meanings or functions when they have been linked to context. This study examines the function of modal verb modalities in speech acts directive in the comic Michel Vaillante.

The purpose of this study is to describe the function of modal verb modalities in directive speech acts on comic Michel Vaillante. The benefits of this research are two, namely theoretical benefits and practical benefits. The theoretical benefits of this research enrich the scientific repertoire, especially in the field of linguistics. The practical benefits of this research can be used as a reference for those who conduct similar research.

The author limits the research to only discuss the verbs of French capital in directive speech acts. Based on the problems discussed in the background of the above problems, the issues that will be examined and discussed are as follows: (1) the strategy of French modal verbs in directive speech acts and (2) the function of French modal verbs in directive speech acts.

\section{Method}

This research was conducted using a qualitative descriptive approach. This approach is done so that the writer can describe the use of French modal modal verbs in directive speech acts. This is in line with Singarimbun (1982: 4) stating that the purpose of descriptive research is to explain, describe an object and fact. At the stage of data collection, the author uses the refer method and is manifested by tapping technique. According to Mahsun (2005: 92), tapping techniques are used not only in oral data but also in written data. The author reads the use of the language of the Michel Vaillant series comic characters by collecting data in the form of sentences containing directive speech acts.

Furthermore, the writer applies a note-taking technique to record the search results of sentences containing modalities in the form of modal verbs from the comic story section of Michel Vaillant. After the data is collected, the author does the next step, analyzing the data. The method used in data analysis is a method with basic techniques for direct elements. The last step is the method of presenting data. The author uses formal and informal methods in presenting the results of data analysis. Sudaryanto (1993) suggests that there are two methods that can be used in the presentation of data, namely formal and informal. Formally, the author presents the results of the analysis in tabular form, and informally presented through words to describe the results of the analysis that must be understood by the reader.

\section{Findings and Discussion}

The analysis shows that there are four functions of modal verb modalities in directive speech acts found in the Michel Vaillant comic based on the realization of Blum Kulka directive speech action strategy. The findings and explanations can be seen below.

\subsection{Modality of verbs modals with strategies are derived from speech locution.}

The illocutionary intention is directly derived from the semantic meaning of speech locus. Usually in this type word must or should be referred to as a statement 
of necessity. The statement of necessity related to the atitude of the speaker in this case is the figures in the Michel Vaillant comic that are based on certainty or uncertainty about the proposition, or in other words, the level of the author's commitment to what he said.

\subsubsection{Modal Verbs Devoir functions "tell"}

The comic characters show a mandatory statement that is through the modal verb devoir (must) as shown in the following data.

1) Maman

Ces haricots verts seront cuits 'al dente; comme il faut! Va plutôt t'occuper des garçons. Vous ne deviez pas discuter?

"These beans will be steamed cooked as they should. Come on, take care of your children. Don't you have to discuss?

Context Mrs. Vaillant was in the kitchen with a waiter, suddenly Mr. Vaillant came and asked that his favorite beans be cooked. Mrs. Vaillant instead told Mr. Vaillant to go and had to take care of her children to discuss.

From data analysis, sentence 1) is a subjunctive modal sentence in the form of interrogative sentences. Judging from the structure of the sentence is terminated (?) And is a complete sentence that has a subject and predicate. Judging from the function, sentence 1) above contains the meaning 'tell' can be shown in the modal verb devoir in the deviez subjunctive mode. Capital verbs deviez subjunctive mode can mean 'tell'. The logic that sentence 1) has a 'tell' function can be shown in the paraphrase of sentences using sentence 1 verb) categorized as an indirect speech act because it tells by speech indirectly. The factors that influence directive speech from sentence 1) are the norm. Norm refers to the rules of interaction and also refers to the interpretation of the speech of the other person. In the sentence above, the norm of interaction can be seen from the function of the directive speech act, the function of telling. In the word that is thickened and tilted deviez "must" the speaker (Madame Vaillante) told the partner to say (Henry Vaillant) to immediately meet his children to discuss the company's problems at hand. Besides being seen from the syntactic construction that deviez capital in the subjunctive mode has the function of giving advice and advice, the context of the sentence also shows the norm of interaction spoken by the speaker to the speech partner. Therefore, sentence 1) proves that the directive speech act functions to have been influenced by the norm.

\subsubsection{Modality of modal verb "Falloir" function "tell"}

2) Jean Pierre : Et nous n'avons for les moyens de créer un réseau de distribution là-bas. II nous faut impressive passer des accords avec une société chinoise.

Michel Vaillant : II me semblait que cette réunion devait nous apporter des nouvelles à ce sujet. 
In data 2) above, the modal verb verb means 'should' to express the attitude of the speakers. However, if sociopragmatic is related to the context of the situation surrounding it, the modal verb faut has the function 'tell'. Speech 2) above contains a statement of the problem marked by modal modal verb modality (= derived from the infinitive falloir verb).

\subsection{Refer to the preparation conditions (Reference to preparatory conditions)}

Examinations contain references to the conditions of preparation, such as willingness, the possibility to do $\mathrm{X}$. This is usually indicated by the verb modalities you want, want to want. In French the use of the preparation statement uses the modal modal pouvoir modality. The following is the data that shows the preparation statement.

\subsubsection{Modal modal verbs "pouvoir" function "suggest"}

What is meant by the function suggest is that speakers expect the speech partner to listen and realize what is suggested by the speaker.

3) Maman

: II est bougon. II râle sur tout. II n'est jamais content dès que je touche de prês ou de loin à ce qui ressemble â une voiture, il s'emporte immédiatement.

"He is angry. He groaned in everything. He was never happy as soon as I touched the car, he was immediately carried away. "

Charlotte : Je sais qu'il a des soucis avec Vaillante, mais est-ce une raison pour être aussi nerveux? II pourrait laisser JeanPierre régler tout ça, non? Are you a besoin, à son âge, de vouloir tout controller?

"I know he has a problem with Valiant, but is that a reason to be very nervous? He can let Jean-Pierre fix all that, right? What does he need, at his age, to want to control everything?"

Context

The conversation occurred when Mrs. Vaillant complained about her problem with her husband to his daughter-in-law Charlotte that the speaker (maman) suggested that the partner (Henry Vaillante her husband) give up his responsibility to his first son Jean-Pierre.

(Graton, MvaNdF, 2015: 10)

From data analysis, utterance 3 ) is a condidional modal sentence in the form of interrogative sentences. Judging from the structure of the sentence is terminated (?) And is a complete sentence that has a subject and predicate. Judging from the function, sentence 3) above contains the meaning "suggest" can be shown in the modal verb pouvoir in conditional pourrait mode. Pourrait modal verb conditional mode can mean 'suggest'. The context of the situation occurred in the living room, there was talk between Michel's mother and Michel's wife, Charlotte. Michel's mother 
complained about her problem with her husband to his daughter-in-law Charlotte that the speaker (maman) suggested that his partner (Henry Vaillante her husband) give up his responsibility to his first son Jean-Pierre.

Sentence 3) is categorized as an indirect speech act because it suggests indirect speech. The factors that influence directive speech from sentence 3) are the norm. Norm refers to the rules of interaction and also refers to the interpretation of the speech of the other person. In the sentence above, the norm of interaction can be seen from the function of the directive speech act, the function suggests. In the word thickened and the tiltrait tilt "can" the speaker (Madame Vaillante) suggested the partner (Henry Vaillant) to hand over his responsibility to his first son named JeanPierre. Besides being seen from the syntactic construction that pourrait capital in conditional mode has the function of giving advice and advice, the context of the sentence also shows the norm of interaction spoken by speakers to the speech partner. Therefore, sentence 3) proves that directive speech acts function suggesting that they have been influenced by the norm.

While the realization of the directive speech action strategy used by Mvm in utterance 3) uses a strategy referring to the preparation situation (Reference to preparatory conditions). Examinations contain references to the conditions of preparation, such as willingness, the possibility to do $X$. Expression makes this type of strategy can be called a preparation statement. As a marker, the availability is pourrait modal verb modality in conditional mode (pourrait comes from v.i = pouvoir).

\subsubsection{Modal Verb Modality 'Pouvoir" functions to "express hope"}

The following is data that shows the preparation statement indicated by modal verb modalities "pouvoir" with the function "expressing hope".

$\begin{array}{ll}\text { 4) Charlotte } & \text { : } \\ \text { Michel } & \text { Qui est-ce? } \\ \text { Charlotte } & \text { Le rosier qui veut nous voir demain. } \\ \text { Michel } & \text { C'est impossible! Voyons! } \\ & \begin{array}{l}\text { Nous pourrons être là, Mardi en début d'après-midi, cela } \\ \text { vous irait? }\end{array} \\ \text { Context } & \begin{array}{l}\text { Conversations occur between Michel Vaillant and his wife, } \\ \text { Charlotte in the living room. Michael hopes his wife can be } \\ \text { present in the race arena tomorrow afternoon. }\end{array}\end{array}$

(Graton, MvaNdF, 2015:)

The directive speech action strategy in speech 4) above is to use a strategy referring to the preparation situation (Reference to preparatory conditions). This is characterized by the use of modal modalities pouvoir verbs in the form of simple futures pourrons. Literally, the pouvoir verb means it can. But if it is associated with the context of the speech surrounding it, then sociopragmatic modality of the pouvoir modal verb in utterance 4) above contains the meaning or function of "hope". This is indicated by the pouvoir verb in the form of a simple futur which states that the event is only at the limit of wishful thinking or is only limited to suggesting it. More precisely the above speech is explained by Michel the character hopes to Charlotte his wife that tomorrow can be on the circuit to watch the race. Therefore the modality of the pouvoir capital verb above serves "expressing hope". 


\subsubsection{Modality of modal verb Pouvoir functions to "suggest"}

The following is data that shows the preparation statement indicated by modal verb modalities "pouvoir" with the function "suggest".

$\begin{array}{ll}\text { 5) Charlotte } & \text { Vous avez une coupe, bientôt, à Portimo. Vous allez } \\ & \text { courir? } \\ \text { Michel } & \text { Je n'ai pa le choix. Eight 'On' investira en formule } 1 \text { which } \\ & \text { is not an association with WTCC est éussite the seulement } \\ & \text { on pouvait retrouver Patrict avant .. } \\ & \text { Conversations still occur between Michel and Carole in the } \\ \text { Context } & \text { company's office space. Michel said that he would like to } \\ & \text { take part in the formula } 1 \text { tournament if he had met his } \\ & \text { Patrict child. }\end{array}$

The directive speech action strategy in speech 4) above is to use a strategy referring to the preparation situation (Reference to preparatory conditions). This is marked by the use of modal modality pouvoir in the form of imparfait pouvait. Literally, the pouvoir verb means it can, can. But if it is associated with the context of the speech surrounding it, then sociopragmatic modalities of the pouvoir modal verb in utterance 5) above contain the meaning or function of "hope". This is indicated by the pouvoir verb in the form of imparfait which states that the event is only at the limit of wishful thinking or is only limited to suggesting it. More precisely the above speech is explained by Michel the character hopes to Charlotte his wife that tomorrow can be on the circuit to watch the race. Therefore the modality of the pouvoir modal verb above serves "expressing hope".

\subsection{Scope stating}

Examinations express explicitly the intentions, desires, or feelings as opposed to the fact that the partner does $X$. Expression makes this type of strategy can be called a statement of desire. The following is the data that shows the preparation statement indicated by the modal verb modality "vouloir" with the function "hope / expectation".

6) Henry Vaillant : Et nous voulons que tu sois notre pilote, Michel. To record the avec toi derrière le volant, defect the aura of the internal retentissement.

Jean-Pierre : Je ne l'oublie is right. J'ai puentenen avec les discipline disciplines de la FIA, ce matin..

Context Henry Vaillant speaks to his son, Jean-Pierre, that he expects Michel to become a rider in the international arena

The directive speech action strategy in utterance 4) above is using the Scope stating strategy. This is characterized by the use of vouloir modal verb modalities in the present indicative form of the voulons. Literally, the vouloir verb means to want. However, if it is associated with the context of the speech surrounding it, the sociopragmatic modality of the modal verb vouloir in utterance 6 ) above contains the meaning or function of "hope". This is indicated by the verb vouloir in the present indicative form. More precisely the speech above is explained by Henry Vaillant to 
Jean-Pierre that tomorrow he hopes Michel will become a rider in the international arena. Therefore the modality modal verb vouloir above serves "expressing hope".

Other data representing the statement of desire strategy is shown by the following data.

6) Michel

Context

$$
\begin{aligned}
& \text { : Je voudrais voir d'abbord ce que vous cacher là, derrièrre } \\
& \text { ce paneau.. }
\end{aligned}
$$

Michel wants to see what is hidden behind the wheel of a car with his child.

The directive speech action strategy in speech 7) above is using the Scope stating strategy. This is characterized by the use of vouloir modal verb modalities in the present indicative form of the voulons. Literally, the vouloir verb means to want. However, if it is associated with the context of the speech surrounding it, the sociopragmatic modality of the vouloir modal verb in utterance 6) above contains the meaning or function of "hope". This is indicated by the verb vouloir in the present indicative form. More precisely the above speech is explained by Michel to Patrict that he wants to see what Patrict has hidden behind the wheel of the car. Therefore the modality modal verb vouloir above have a function "declaring the request".

\section{Conclusion}

From the analysis, it can be concluded that modal verb modalities in directive speech acts of the figures in Michel Vaillant comics include having the function of telling, suggesting, expressing expectations, and expressing requests. These functions are based on the speech action strategy used by comic characters. There are three realization of directive speech action strategies that are used which influence the function of modal verb modalities in the directive action on Michel Vaillant comics, namely strategy strategies derived from speech locus, strategies referring to the state of preparation, and strategy of expressing wishes. The benefits of this research are two, namely theoretical benefits and practical benefits. The theoretical benefits of this research enrich the scientific repertoire, especially in the field of linguistics. The practical benefits of this research can be used as a reference for those who conduct similar research.

\section{References}

Alwi, H. (1992). Modalitas dalam Bahasa Indonesia. Yogyakarta: Kanisius.

Dubois, J. (1969). Grammaire Structurale du Français: La Phrase et Les Transformations. Paris: Librairie Larousse.

Fintel, K. (2006). "Modality and Language". In Encyclopedia of Philosophy-Second Edition, edited by Donald M.Borchert. detroit: MacMillan Reference USA. http://mit.edu/fintel/www/modality.pdfGrice, H.P. 1989. Studies In The Way Of Words. England: Harvard University Press.

Leech, Geoffrey. 1983. Principles of Pragmatics. London and New York: Longman.

Leech, Geoffrey. 1993. Prinsip-prinsip Pragmatik. M. D. D. Oka, Penerjemah. Jakarta: UI Press. Terjemahan dari: Leech, Geoffrey. 1983. The Principles of Pragmatics. New York: Longman Group Limited. 
L'Huillier, Monique. 1999. Advanced French Grammar. New York: Cambridge University Press.

Mahsun, MS. 2005. Metode Penelitian Bahasa. Jakarta: PT Raga Grafindo Persada

Nadar, F. X. 2009. Pragmatik dan Penelitian Pragmatik. Yogyakarta: Graha IImu

Searle, J.R. 1976. Speech Act An Essay in the Philosophy of Language. Cambridge: Cambridge University Press.

Searle, J.R. 1985. Foundations of Illocutionary Logic. Cambridge: Cambridge University Press.

Singarimbun, Masri dan Efendi. 1982. Metode Penelitian Survei. Jakarta: LP3ES.Fathiyah Amatullah, dkk. (2016). Penulis Cilik Indonesia: Mahkota Surga untuk Ayah. Surakarta: Lintang

Sudaryanto. 1993. Metode dan Aneka Teknik Analisis Bahasa: Pengantar Penelitian Wahana Kebudayaan Secara Linguistik. Yogyakarta: Duta Wacana University Press.

Ubaidillah. 2018. Tindak Tutur Direktif Ujaran Kebencian Di Media Sosial Di Indonesia. Yogyakarta: FIB UGM 